\title{
Comparison of fin-and-tube interlaced and face split evaporators with flow maldistribution and compensation
}

\author{
Kærn, Martin Ryhl; Elmegaard, Brian; Larsen, Lars Finn Sloth
}

Published in:

International Journal of Refrigeration

Link to article, DOI:

10.1016/j.jrefrig.2012.10.006

Publication date:

2013

Link back to DTU Orbit

Citation (APA):

Kærn, M. R., Elmegaard, B., \& Larsen, L. F. S. (2013). Comparison of fin-and-tube interlaced and face split evaporators with flow maldistribution and compensation. International Journal of Refrigeration, 36(1), 203-214. https://doi.org/10.1016/j.jijrefrig.2012.10.006

\section{General rights}

Copyright and moral rights for the publications made accessible in the public portal are retained by the authors and/or other copyright owners and it is a condition of accessing publications that users recognise and abide by the legal requirements associated with these rights.

- Users may download and print one copy of any publication from the public portal for the purpose of private study or research.

- You may not further distribute the material or use it for any profit-making activity or commercial gain

- You may freely distribute the URL identifying the publication in the public portal 


\title{
Comparison of fin-and-tube interlaced and face split evaporators with flow maldistribution and compensation
}

\author{
Martin Ryhl Kærn ${ }^{\mathrm{a}, 1, *}$, Brian Elmegaard ${ }^{\mathrm{a}}$, Lars Finn Sloth Larsen ${ }^{\mathrm{b}, 2}$ \\ ${ }^{a}$ Department of Mechanical Engineering, Technical University of Denmark, Nils Koppels Allé Bygn. 403, DK-2800 Lyngby, Denmark \\ ${ }^{b}$ Danfoss A/S, Refrigeration and Air-Conditioning, Nordborgvej 81, DK-6430 Nordborg, Denmark
}

\begin{abstract}
Flow maldistribution in fin-and tube evaporators for residential air-conditioning is investigated by numerical simulation. In particular, the interlaced and the face split evaporator are compared in flow maldistribution conditions. The considered sources of maldistribution are the liquid/vapor distribution and the airflow distribution. Furthermore, compensation of flow maldistribution by control of individual channel superheat is studied for each evaporator type. It is shown that the interlaced evaporator is better at flow maldistribution than the face split evaporator. However, if individual channel superheats are controlled, the face split evaporator achieves the best performance, i.e. an increase of $7 \%$ in overall UA-value and $1.6 \%$ to $2.4 \%$ in COP compared to the interlaced evaporator without compensation.
\end{abstract}

Keywords:

Flow distribution, Compensation, Air-conditioning, Finned tube, Modelling, Simulation

\section{Nomenclature}

\section{Roman}

COP coefficient of performance (-)

$F_{x}$ phase distribution parameter (-)

$F_{\text {air }}$ airflow distribution parameter (-)

$L_{t}$ transverse coil length $(\mathrm{m})$

$U$ velocity $\left(\mathrm{m} \mathrm{s}^{-1}\right)$

UA overall heat transfer coefficient $\left(\mathrm{W} \mathrm{K}^{-1}\right)$

$x$ vapor quality (-)

$y$ transverse coordinate (-)

\section{Subscripts}

in inlet

$m$ mean

\section{Introduction}

For A-shaped fin-and-tube evaporators in residential air-conditioning (RAC), the chosen type of circuitry by the manufacturers changed a couple of years ago. It

\footnotetext{
${ }^{*}$ Corresponding author. Tel.: +45 4525 4121; Fax: +45 4593 5215.

Email address: pmak@mek.dtu.dk (Martin Ryhl Kærn)

${ }^{1}$ Former address: Danfoss A/S, Refrigeration and AirConditioning, Nordborgvej 81, DK-6430 Nordborg, Denmark

${ }^{2}$ Present address: Vestas Technology R\&D, Hedeager 42, DK8200 Aarhus N, Denmark
}

changed from the face split to the interlaced circuitry, see figure 1 . The interlaced circuitry shows a significant increase in cooling capacity compared to the face split circuitry. The main reason is the better compensation of flow maldistribution by design. In the current paper this choice is discussed with regards to further compensation of flow maldistribution by control of individual channel superheats.

Flow maldistribution in fin-and-tube evaporators has been shown to decrease the performance of the evaporator and the system both experimentally (Payne and Domanski, 2003) and numerically (Kærn et al., 2011b; Kim et al., 2009b). Both air side and refrigerant side effects may cause flow non-uniformities, e.g. nonuniform airflow, air-temperature, humidity or frost, fouling, two-phase inlet distribution, feeder tube bending and improper heat exchanger design. In this study we only address non-uniform airflow and non-uniform liquid/vapor distribution to the evaporator.

Most efforts of compensating flow maldistribution have been addressed to the design of the evaporator circuitry. Domanski and Yashar (2007) applied a novel optimization system called ISHED (intelligent system for heat exchanger design) to optimize refrigerant circuitry in order to compensate airflow maldistribution. They measured the air velocity profile using particle image velocimetry (PIV) and used that as input to their numer- 
a

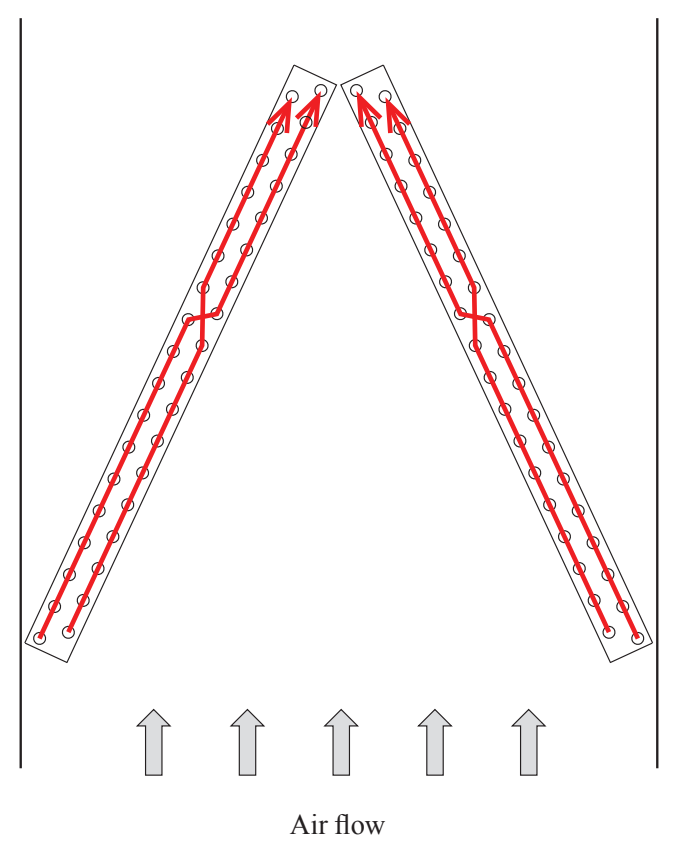

b

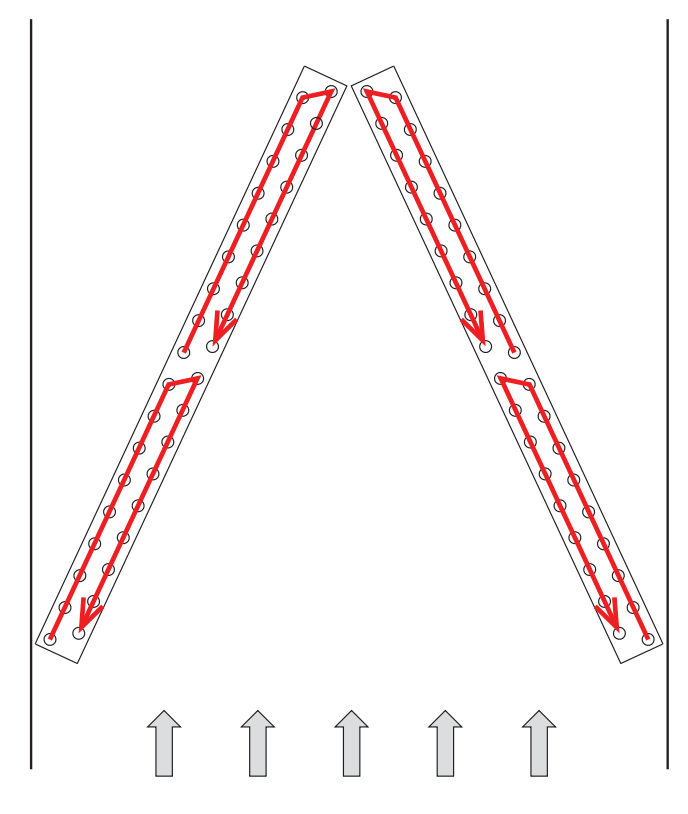

Air flow

Figure 1: Tube circuitries of (a) the interlaced evaporator and (b) the face split evaporator

ical model and reported that the cooling capacity was increased by $4.2 \%$ compared to an interlaced type of circuitry.

Studies regarding the benefits by control of individual superheat have also been conducted. Payne and Domanski (2003) showed experimentally that the performance degradation due to a non-uniform airflow could be recovered to within $2 \%$ of the original cooling capacity at uniform airflow conditions. Kim et al. (2009a) studied benefits of upstream vs. downstream control of individual channel superheat on a fin-and-tube five channel R410A heat pump numerically. The study showed that the upstream control outperformed the downstream control. They found that upstream control was able to recover up to $99.9 \%$ of the penalties of maldistribution. Kærn et al. (2011a) also studied compensation by control of individual channel superheat. Here a recovery of $94.3 \%$ in COP was found at a nearly complete air blockage of half of the evaporator, keeping the total air volume flow constant.

To this point no other investigation than the current is known to the authors where tube circuitries are compared with flow maldistribution and compensated by control of individual channel superheat. The objective of this paper is to study the benefits (in UA-value and $\mathrm{COP}$ ) of compensation by control of individual chan- nel superheats on the interlaced and the face split evaporator types. The method of compensation involves a coupled expansion and distributor device (FunderKristensen et al., 2009), which is able to distribute the mass flow according to the individual superheat of each channel by only measuring the overall superheat after the manifold. The device does not provide continuous refrigerant flow into each channel, but rather discontinuous individual channel injection (modulation of each channel flow). The optimal distribution of mass flow rate (or individual refrigerant injection) is found from a distribution analysis performed at specific points in time during operation, see Mader and Thybo (2010). The distribution analysis is essentially carried out by control algorithms, where the importance of each individual channel on the overall superheat is measured in order to find the optimal distribution.

This paper includes a brief description of the numerical model, an analysis of flow maldistribution in both evaporators and compensation by control of individual channel superheat.

\section{Simulation model}

A model of an $8.8 \mathrm{~kW}$ R410A RAC system was developed by Kærn et al. (2011b) in Dymola 7.4 (2010), 
and it has been updated in this study to include the tube circuiting effects of the evaporator as described in Kærn (2011). Thermophysical properties for R410A are obtained from the refeqns package (Skovrup, 2009). In order to predict the refrigerant maldistribution in the evaporator, a distributed one-dimensional mixture model was chosen. For the condenser, the simpler moving boundary model of Zhang and Zhang (2006) was chosen, which averages the vapor, two-phase and liquid regions. Both the evaporator and condenser models include dynamics of refrigerant charge and energy content, so that further investigations are possible with regards to the dynamics of the system. Only steady state results are given in this paper. The models of the expansion and compressor are quasi-static. Momentum transfer and frictional pressure drop are addressed in the evaporator tubes, U-bends and feeder tubes only, in order to predict the mass flow distribution in the evaporator.

\subsection{Geometry}

Table 1 shows the main geometry of the test case evaporator and condenser. The tube inner walls are smooth. Furthermore, the feeder tubes to the evaporator have an internal diameter of $3 \mathrm{~mm}$ and a length of $300 \mathrm{~mm}$. Note that the coil geometry is the same for both the interlaced and face split evaporator, however the tube connections or circuiting are different as shown in figure 1.

Table 1: Main geometry of the evaporator and condenser

\begin{tabular}{lcc}
\hline & Evaporator & Condenser \\
\hline Number of coils & 2 & 1 \\
Number of channels in each coil & 2 & 5 \\
Number of tubes rows & 2 & 1 \\
Number of tubes per row & 18 & 30 \\
Tube length [mm] & 444.5 & 2100 \\
Inner tube diameter [mm] & 7.6 & 7.6 \\
Outer tube diameter [mm] & 9.6 & 9.6 \\
Transverse tube pitch [mm] & 25.4 & 25 \\
Longitudinal tube pitch [mm] & 21.25 & \\
Fins & Louvred & Louvred \\
Fin pitch [mm] & 1.81 & 1.15 \\
Total outside area [m ${ }^{2}$ ] & 17.3 & 52.2 \\
Number of cells per tube (in model) & 3 & \\
Number of cells per channel (in model) & $3 \cdot 18$ & \\
\hline
\end{tabular}

\subsection{Assumptions and correlations}

The two coils in the evaporator are assumed to be in similar maldistribution conditions. Furthermore, the air flows through the coil one-dimensionally and perpendicularly to the coil as illustrated on figure $2 \mathrm{a}$. This means that each tube in the second tube row sees the average velocity (from mass conservation) and outlet air state (from energy conservation) of the incoming air streams. For example, referring to figure 2 a, tube $N+2$ sees the average velocity and outlet state of tube 2 and 3.

Each tube is discretized into smaller cells as illustrated on figure $2 \mathrm{~b}$, i.e. control volumes of air, wall and refrigerant. Each discrete cell is calculated as a small heat exchanger with uniform transport properties. Mass, momentum and energy conservation equations are applied to the refrigerant in each cell, where homogeneous flow and thermodynamic equilibrium are assumed. Furthermore, changes in kinetic and potential energies are neglected. It is assumed that the tube walls have rotational symmetry (no azimuthal heat conduction) and negligible axial heat conduction. Mass and energy conservation equations are applied to the air, which is assumed to be dry. Similar assumptions are used in the condenser model of the refrigerant and airflow, however the heat resistance and the dynamics in the condenser wall are neglected. The used correlations for both the evaporator and the condenser are given in table 2. Furthermore, effectiveness-NTU relations for cross flow heat exchangers are employed.

\begin{tabular}{ll}
\multicolumn{2}{c}{ Table 2: Overview of used correlations. } \\
\hline $\begin{array}{l}\text { Air-side } \\
\text { Fin efficiency }\end{array}$ & $\begin{array}{l}\text { Wang et al. (1999) } \\
\text { Schmidt (1949) } \\
\text { (Schmidt approximation) }\end{array}$ \\
\hline Single-phase & Gnielinski (1976) \\
Heat transfer & Blasius (2002) \\
$\begin{array}{l}\text { Friction } \\
\text { Bend friction }\end{array}$ & Ito (1960) \\
\hline $\begin{array}{l}\text { Two-phase (evaporator) } \\
\text { Heat transfer }\end{array}$ & Shah (1982) \\
Friction & Müller-Steinhagen and \\
Bend friction & Heck (1986) \\
\hline Two-phase (condenser) & Geary (1975) \\
Heat transfer & Shah (1979) \\
\hline
\end{tabular}

In the condenser, refrigerant enters four of the channels and is mixed before entering the fifth channel. Since maldistribution is not addressed in the condenser, it is assumed to be four straight tubes with no maldistribution.

The expansion valve is modeled as an isenthalpic process and it essentially controls the superheat out of the evaporator manifold by the mass flow rate through the valve. The manifold is modeled by mixing of the refrigerant streams, i.e. mass and energy conservation equa- 
$\mathbf{a}$

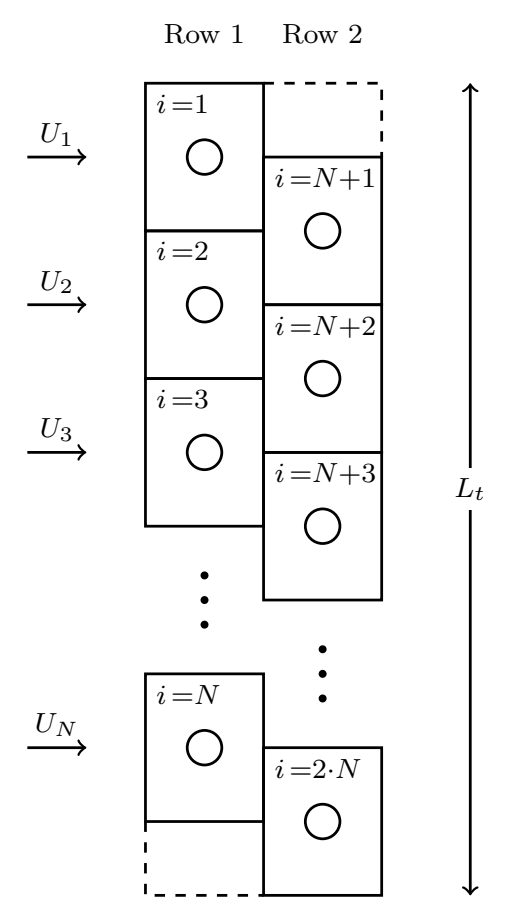

b

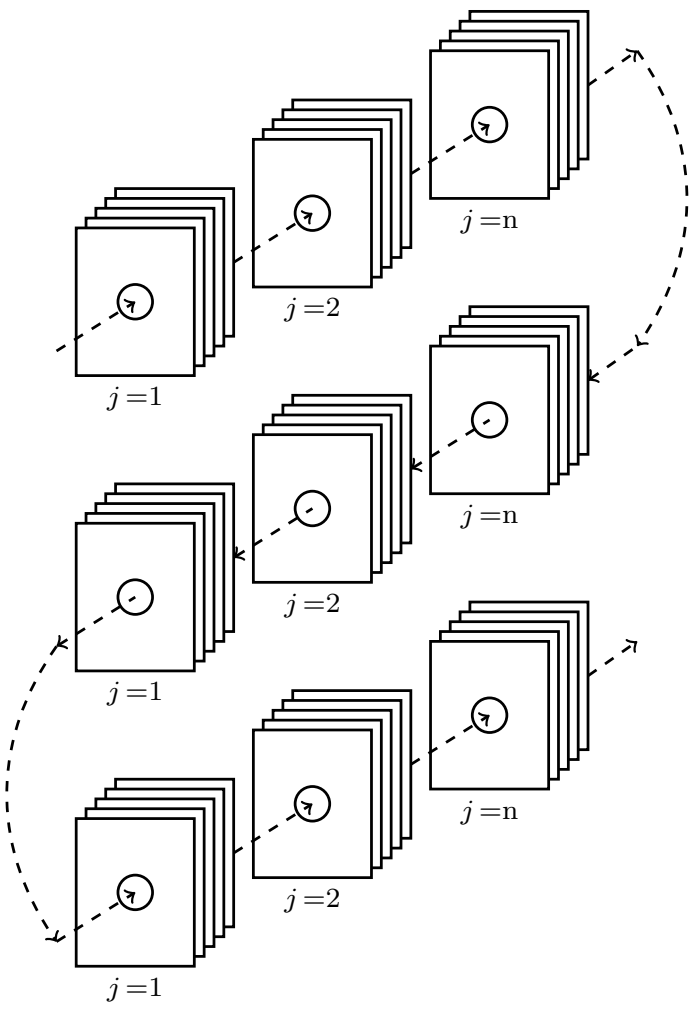

Figure 2: Sketch of the evaporator model and cells; airflow across each tube denoted by $i$ (a) and refrigerant flow cells in each tube denoted by $j$. $N$ is number of tubes per row and $n$ is number of cells per tube. 
tions are applied. The geometric volume flow of the compressor is $6.239 \mathrm{~m}^{3} \mathrm{~h}^{-1}$, and polynomials from the rating of the compressor (ANSI/AHRI Standard 540, 2004) are used to compute the isentropic and volumetric efficiencies.

\subsection{Distribution parameters}

To study the effect of inlet liquid/vapor phase distributions and non-uniform airflow distributions, we have defined two distribution parameters. Referring to figure 3 , the phase distribution parameter, $F_{x}$, is defined by

$$
F_{x}=\frac{x_{2}}{x_{\text {in }}}
$$

When $F_{x}$ is unity, the vapor quality into the feeder tubes is equal. When $F_{x}$ is zero, only liquid is fed into channel 2. Mass and energy conservation equations are applied to compute the vapor quality into channel 1 . The numbering of the channels for both the interlaced and the face split are shown in figure $3 \mathrm{a}$. The airflow distribution parameter, $F_{\text {air }}$, is defined by

$$
U(y)=U_{m} F_{\text {air }}+y \frac{2 U_{m}\left(1-F_{\text {air }}\right)}{L_{t}}
$$

where $U_{m}$ is the mean frontal velocity, $y$ is the transverse coordinate and $L_{t}$ is the transverse length of the coil. When $F_{\text {air }}$ is unity, the airflow profile is uniform across the coil. When $F_{\text {air }}$ is zero, the airflow profile becomes the worst possible linear one-dimensional profile in the transverse direction, see figure $3 \mathrm{~b}$.

\subsection{Boundary conditions}

In the system model the overall superheat is kept at $5 \mathrm{~K}$. When compensating, the expansion and distributor device controls both channel superheats to $5 \mathrm{~K}$. Note that the actual algorithm of the expansion and distributor device (Funder-Kristensen et al., 2009; Mader and Thybo, 2010) is not modeled for simplicity. In contrast, each channel superheats are controlled by continuous integral controllers. For these reasons, any other control approach that insures equal channel superheats should give similar results, e.g. individual valves or hybrid control as used by Kim et al. (2009a).

During start-up of the simulation at no maldistribution, the charge of the system is determined so that the subcooling becomes $2 \mathrm{~K}$. Then the different distribution parameters are varied individually and each steady state result is obtained. The indoor and outdoor air temperatures are $26.7^{\circ} \mathrm{C}$ and $35^{\circ} \mathrm{C}$, respectively. The mean frontal air velocities are 1.16 and $0.68 \mathrm{~m} \mathrm{~s}^{-1}$ to the evaporator and condenser, respectively.

\section{Results}

In this section the results of the simulations of flow maldistribution are presented for each circuitry type, i.e. the interlaced and the face split evaporator. The distribution parameters are varied individually from 1 to 0 , imposing an increasing degree of maldistribution. Firstly, we consider the cases without compensation and, secondly, we consider the case with compensation by control of individual superheat.

\subsection{Maldistribution from the distributor without com- pensation}

The distribution of refrigerant mass flux as function of the phase distribution parameter is shown in figure $4 \mathrm{a}$ for each coil of the evaporators. It shows that the mass flux distribution is dependent on $F_{x}$ so that more mass comes through the channel with lower inlet vapor quality (channel 2) and less mass comes through the channel with higher inlet vapor quality (channel 1). This is determined by the pressure drop through the channels plus its feeder tubes that must be equal. Indeed more mass will travel through the channel with lower vapor quality, since the pressure drop of the liquid phase is lower than the pressure drop of the vapor phase. At no maldistribution $\left(F_{x}=1\right)$ the face split evaporator shows higher mass fluxes for both channels indicating a higher cooling capacity, however, they decrease at higher maldistribution and become lower than the interlaced evaporator around $F_{x}=0.55$.

The consequence of the refrigerant maldistribution is seen in figure $4 \mathrm{~b}$, which shows the individual channel superheats for each coil of the evaporators. At $F_{x}=$ 0.85 , liquid is flowing out of channel 2 for the face split evaporator. This point is important because the twophase area of the face split evaporator decreases, when full evaporation is not reached in channel 2. A larger superheated area in channel 1 is required in order to evaporate this surplus liquid, thus the overall UA-value decreases as seen in figure $4 \mathrm{c}$. The interlaced evaporator does not experience the same degree of superheat nonuniformity, and it therefore has a smaller reduction in the overall UA-value as $F_{x}$ decreases. Figure 5 and 6 show that the superheat may actually increase and decrease in the second tube row of the interlaced evaporator, which somehow contradicts the better performance at higher liquid/vapor maldistribution. The air is thus cooled in the first row and heated in the second, which should be avoided.

The face split evaporator performs better at low maldistribution. This is because of the tube circuitry. The 
a

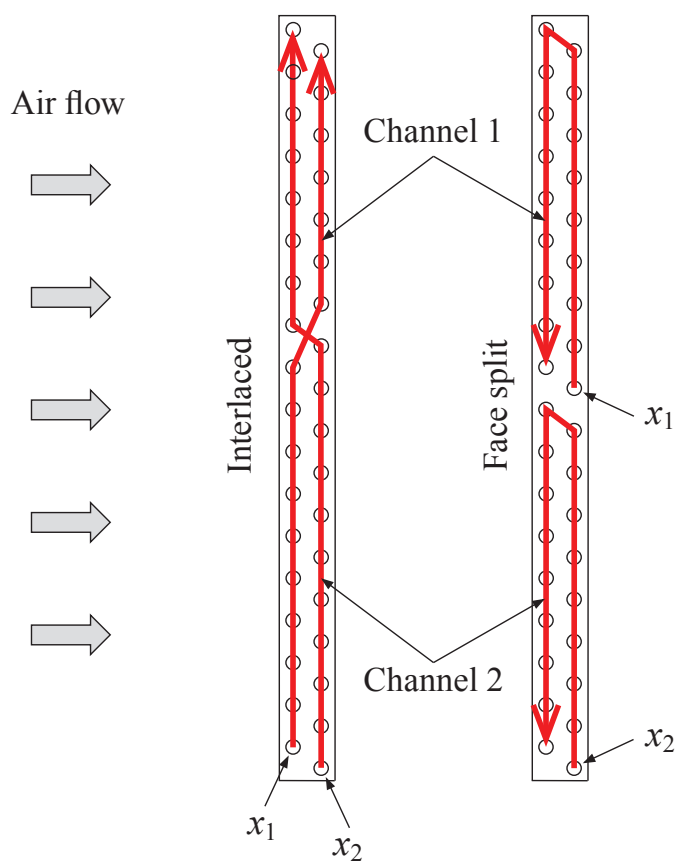

b

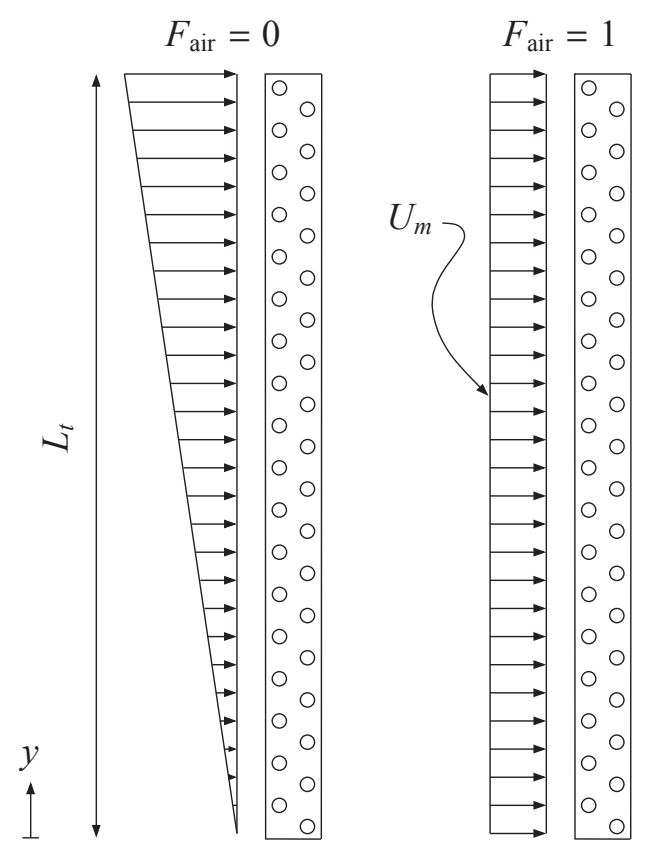

Figure 3: (a) channel numbering for each evaporator and (b) one-dimensional airflow profiles.

two channels of the face split evaporator are countercross flow, however, the interlaced is both countercross flow (channel 2) and parallel/cocurrent-cross flow (channel 1). When constructing a heat exchanger it should always be attempted to use the temperature potential between the heat exchanging fluids in the best possible way. It is not the case when the superheated regions, which have lower UA-value, are aligned next to each other in the airflow direction. This is the case for the interlaced evaporator as illustrated in figure 5 . There is a higher temperature potential for heat transfer in both the superheated regions of the face split evaporator, since they are aligned in the first tube row. In turn, the face split evaporator will minimize the superheated region better, since the gradient of the refrigerant vapor temperature is higher than for the interlaced evaporator at no maldistribution, see figure 6 for $F_{x}=1$.

The COP of the two systems (figure 4d) is affected in similar manner as the UA-value, however, not as dramatic. The COP decrease is mainly caused by the decrease in evaporating temperature and pressure as shown in figure 6 and 7, respectively, but also affected by the associated change in isentropic efficiency of the compressor, however, not as significant. The tradeoff between the face split and the interlaced evaporator is at
$F_{x}=0.55$ for the current systems.

Figure $7 \mathrm{a}$ and $7 \mathrm{~b}$ show the $\log p-h$ diagrams for the two systems at different phase distribution parameters. The figure illustrates how the liquid/vapor maldistribution affects the system operation points. It is seen that the liquid/vapor maldistribution in the evaporator does not affect the liquid subcooling much in the cycle as may be expected, since the charge is fixed during initialization of the simulations and since channel 2 receives and holds-up more liquid.

In addition, the $\log p-h$ diagrams are zoomed-in on the evaporator subsystem as shown in figure $7 \mathrm{c}$ and $7 \mathrm{~d}$. The figures illustrate the refrigerant states through the distributor, the feeder tubes, the evaporator channels in each coil of the evaporator and the manifold for both systems. They explain why figure 6 shows different refrigerant temperatures at the inlet to the evaporator channels. The reason is that the different pressure drop through each feeder tube is lower for decreasing vapor quality, and thus results in different inlet refrigerant temperatures in figure 6 . Note that the limit $F_{x} \rightarrow 0$ almost results in invalid results, since the distribution to channel 1 approaches superheated refrigerant, which cannot occur if thermodynamic equilibrium prevails in the distributor. 
$\mathbf{a}$

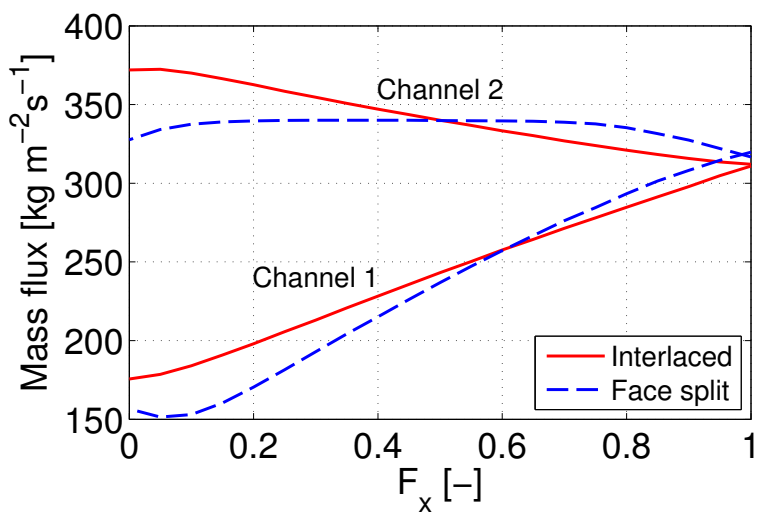

c

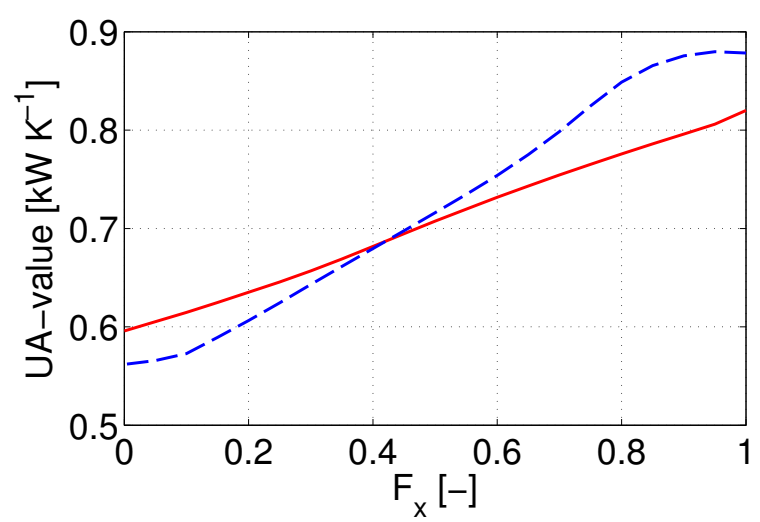

b

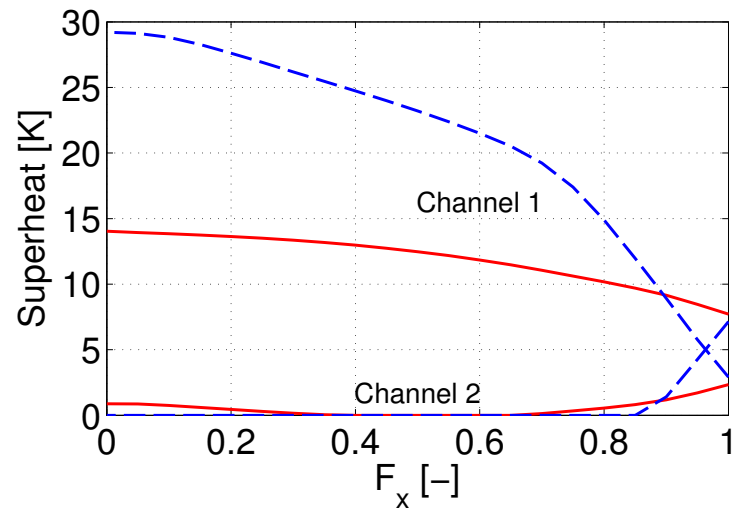

d

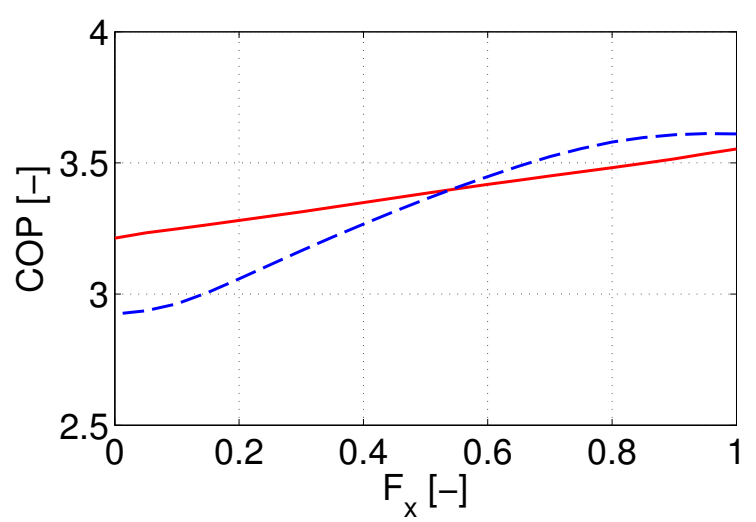

Figure 4: Selected parameters vs. the phase distribution parameter.

\subsection{Maldistribution from the airflow without compen-} sation

The distribution of refrigerant mass flux as function of the airflow distribution parameter is shown in figure $8 \mathrm{a}$ for each coil of the evaporators. For the face split evaporator, the refrigerant mass flux distribution is almost equal in each channel as $F_{\text {air }}$ decreases. For the interlaced evaporator there is some divergence. The mass fluxes are again higher for the face split evaporator at low maldistribution indicating a higher cooling capacity and performance. However, the mass fluxes of the face split evaporator decrease even more than the interlaced evaporator at higher maldistribution.

Figure $8 \mathrm{~b}$ shows the corresponding superheat of each channel in the coils of both evaporators. It is seen that the interlaced evaporator recovers the airflow maldistribution quite well, i.e. the superheated region of the evaporator is not increased. This is in contrast to the face split evaporator, which shows that liquid comes out of channel 2 at $F_{\text {air }}=0.75$, thus the superheat of channel
1 increases in order to ensure an overall superheat of 5 $\mathrm{K}$.

Figure 9 and 10 show the refrigerant temperature contours in the coils and profiles following the refrigerant channel flows. For the interlaced evaporator the superheated zone is larger at the beginning, but actually becomes smaller as $F_{\text {air }}$ decreases. This is because of the larger heat transfer due to higher air velocity across the top of the coil, thus resulting in larger vapor temperature gradient. The face split evaporator shows the minimum superheated area at no maldistribution, however, it increases at higher airflow maldistribution.

Figure 11 shows the $\log p-h$ diagrams and the zoomed-in $\log p-h$ diagrams of the evaporator subsystem for the interlaced and face split evaporators at different airflow distribution parameter. Again, the liquid subcooling is not affected much by the flow maldistribution. In addition, the evaporating pressure is higher for the face split evaporator at no maldistribution, however, it decreases much more than the interlaced evaporator 
Interlaced

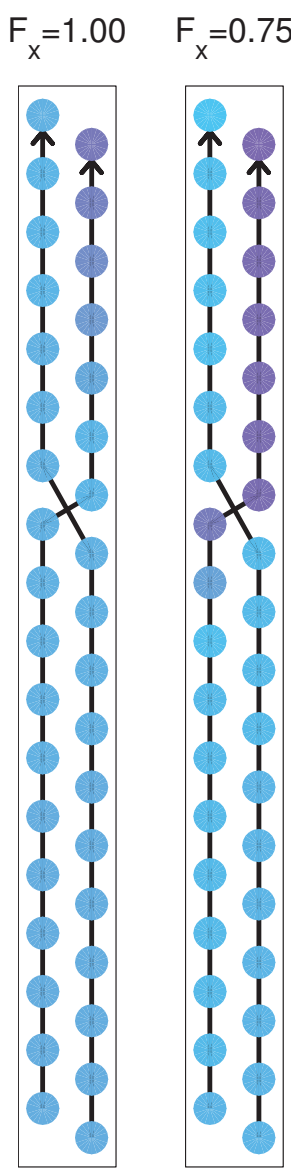

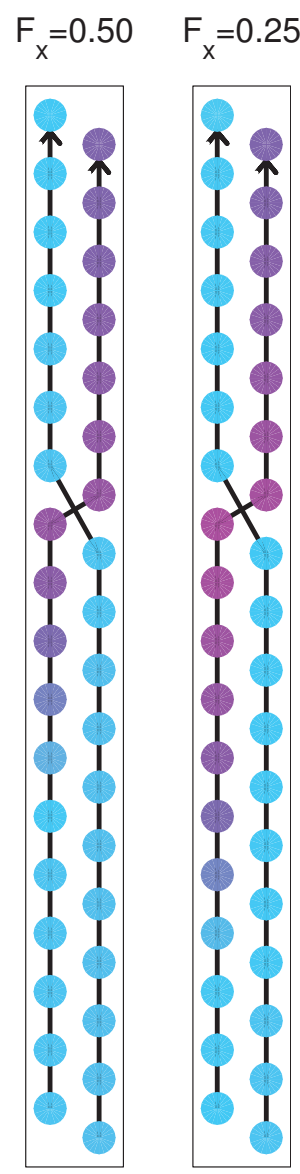
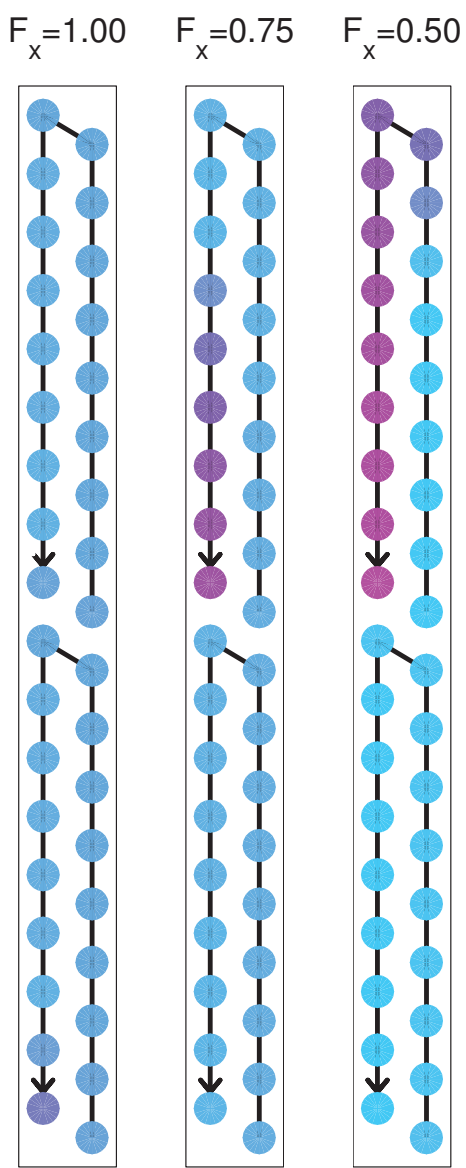

$F_{x}=0.25$
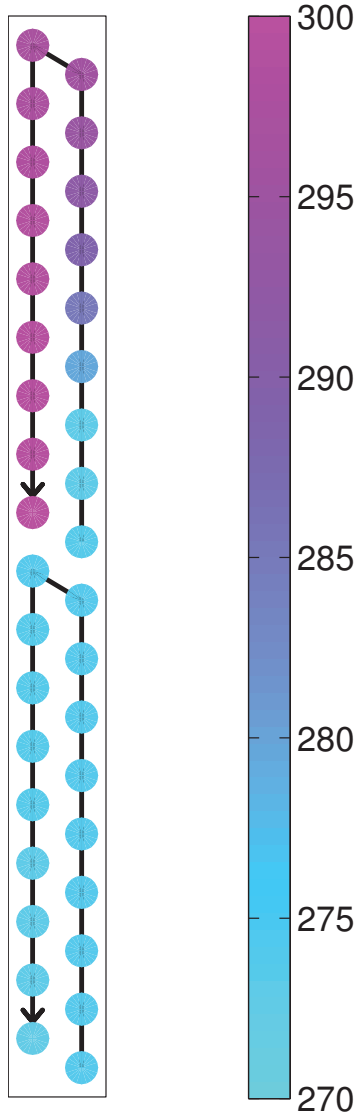

Figure 5: Refrigerant temperature contours through center of coils.

$\mathbf{a}$

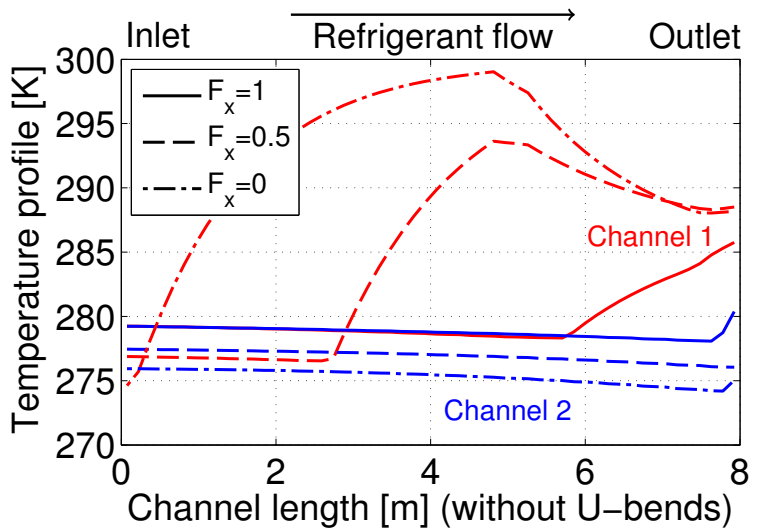

b

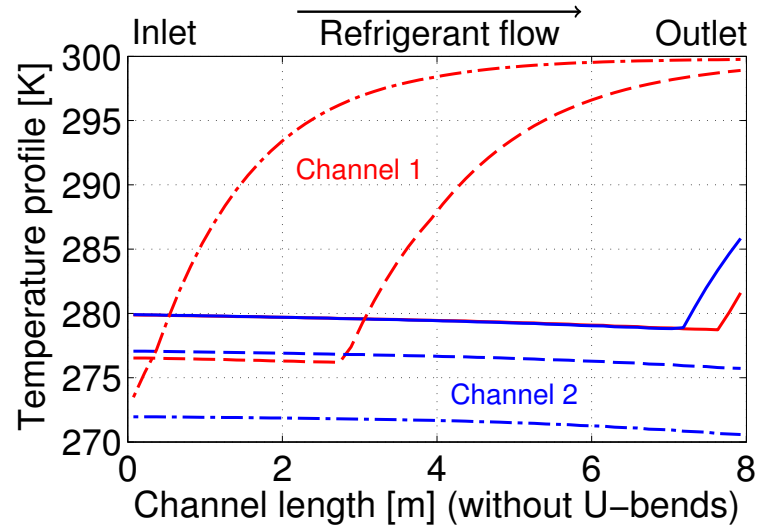

Figure 6: Refrigerant temperature profile for interlaced (a) and face split (b) coils at different phase distribution parameters. 
$\mathbf{a}$

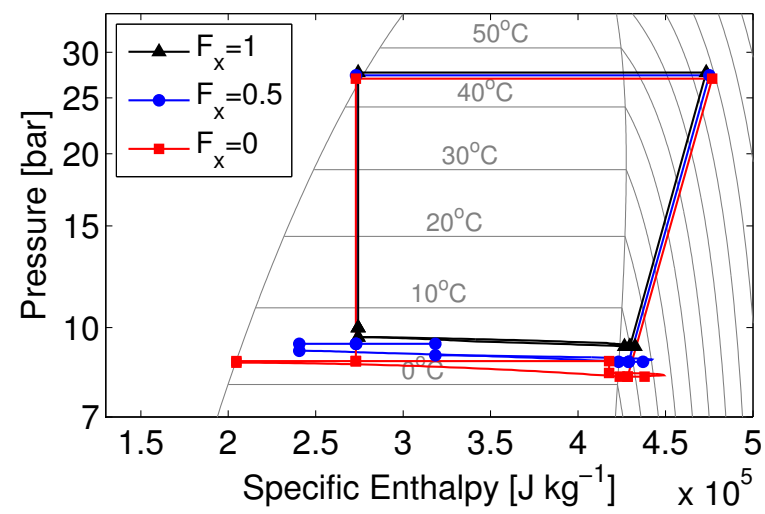

c

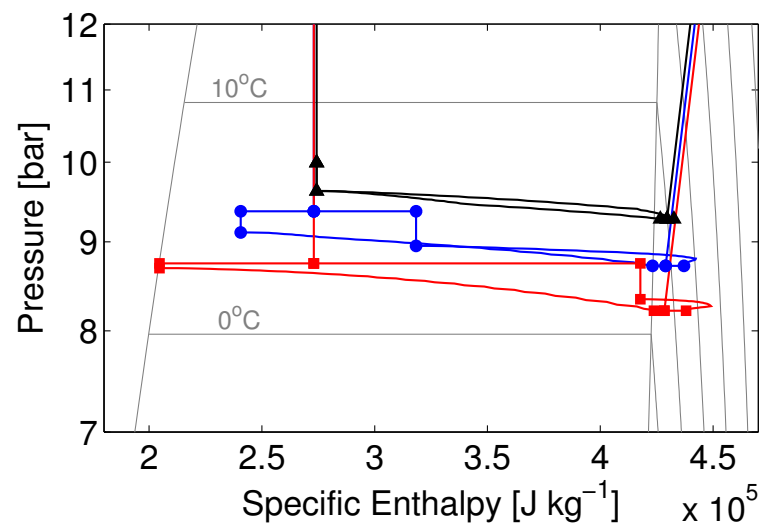

b

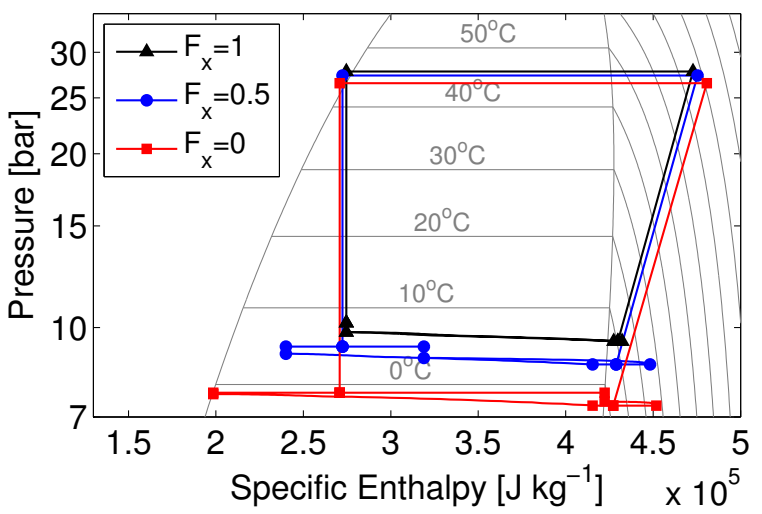

d

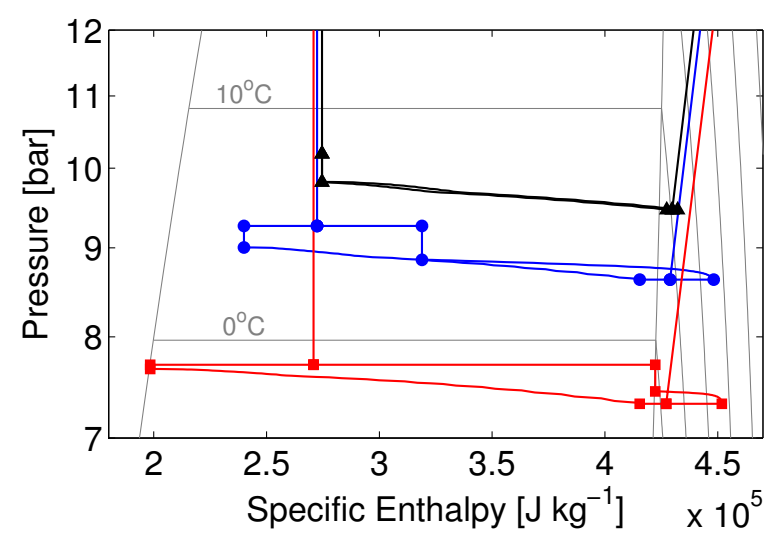

Figure 7: $\log p-h$ diagram for interlaced $(\mathrm{a}, \mathrm{c})$ and face split $(\mathrm{b}, \mathrm{d})$ systems at different phase distribution parameters.

at increased airflow maldistribution resulting in a lower COP.

Despite the interlaced superior flow maldistribution recovery, the face split evaporator performs better at $F_{\text {air }}$ $>0.55$ and $F_{x}>0.55$ in terms of overall UA-value and COP, see figure $4 \mathrm{c}, 4 \mathrm{~d}, 8 \mathrm{c}$ and $8 \mathrm{~d}$. As mentioned in the previous section, this is because the superheated regions with low UA-value are placed in the first row of the coils in the face split evaporator, where the temperature driving potential is highest. It seems a coincidence that the trade-off value is 0.55 for both $F_{\text {air }}$ and $F_{x}$, however, the trade-off is subject to their definitions from equation 1 and 2 . The reason why the interlaced evaporator is the chosen type today seems because of the flow maldistribution, which is better recovered by the interlaced evaporator.

\subsection{Compensation of flow maldistribution by control of individual channel superheat}

The method of compensation involves a coupled expansion and distributor device, which is able to distribute the mass flow according to the individual superheat of each channel by only measuring the overall superheat (Funder-Kristensen et al., 2009; Mader and Thybo, 2010). The distribution occurs before the expansion, and the actual expansion is occurring into the individual feeder tubes. Thus the liquid/vapor phase cannot be maldistributed. The expansion device is distributing the liquid and vapor phases uniformly. Moreover, the inlet specific enthalpy to each channel is the same, and the expansion device already compensates the liquid/vapor maldistribution. Thus, in this section we only vary the airflow distribution parameter. By allowing the individual mass flows to be controlled, the pressure drop through each channel is not necessarily equal. Therefore, an additional inlet pressure difference is allowed 
$\mathbf{a}$

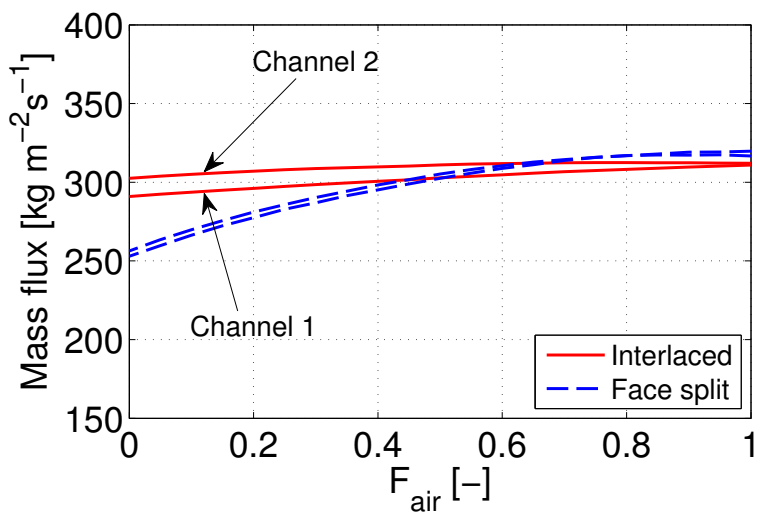

c

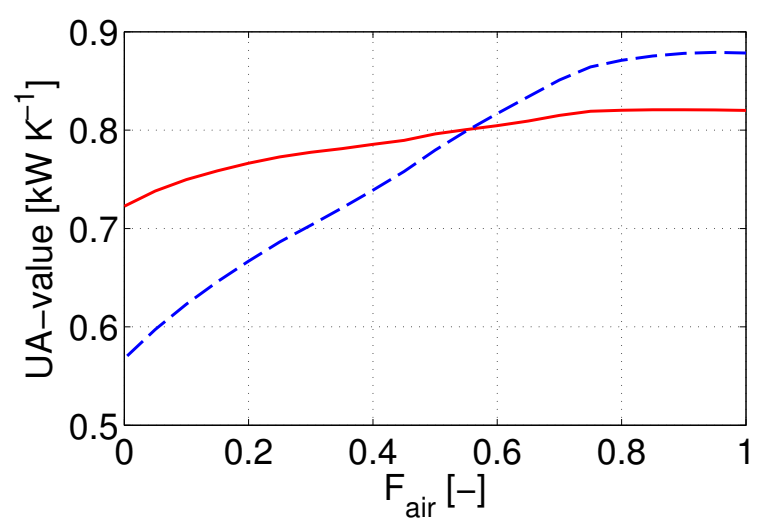

b

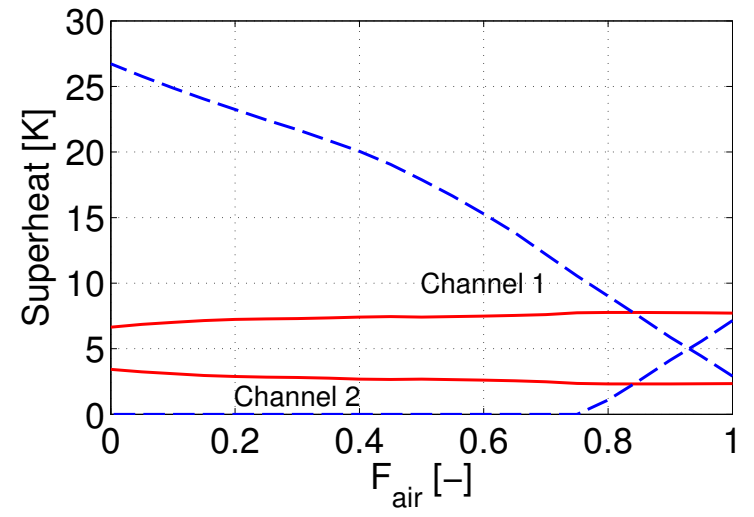

d

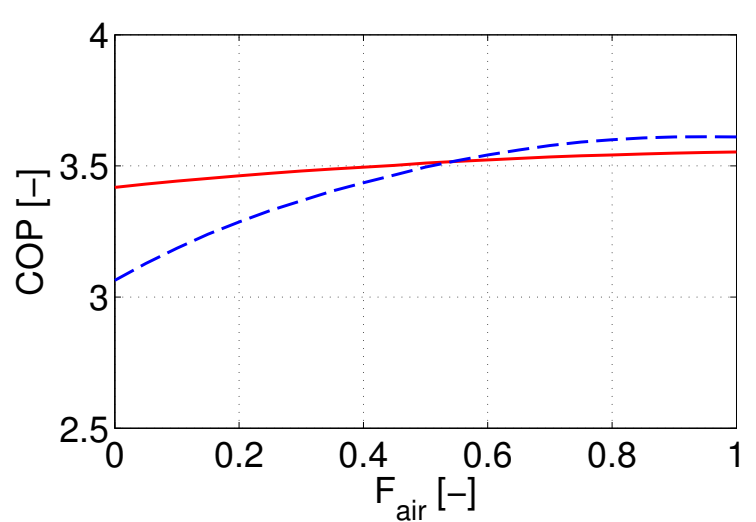

Figure 8: Selected parameters vs. the airflow distribution parameter.

in the model. Figure 12 shows the UA-value and COP as $F_{\text {air }}$ goes from 1 to 0 .

It shows that the control of individual channel superheat reduces the superheated regions in both evaporators at flow maldistribution. The reduction in the superheated region is, however, higher for the face split evaporator, as indicated when comparing figure 10 and 12, since the interlaced evaporator already by design compensates airflow maldistribution to some extent. The result is an increased overall UA-value and COP as depicted in figure $12 \mathrm{a}$ and $12 \mathrm{c}$.

Both evaporators experience a better performance when controlling the individual superheat. Despite the better performance of the interlaced evaporator with compensation, it does not perform better than the face split evaporator without compensation at $F_{\text {air }}>0.65$. The face split evaporator with compensation performs the best at all values of $F_{\text {air }}$. Interestingly, the difference in COP between the two evaporators with compensation is increasing slightly with increasing airflow maldistri- bution.

If we normalize the results from figure $12 \mathrm{a}$ and $12 \mathrm{c}$ with the current evaporator used today, i.e. the interlaced without individual superheat control, we see the actual increase in performance when applying the compensation method to each systems as function of $F_{\text {air }}$, see figure $12 \mathrm{~b}$ and $12 \mathrm{~d}$. For the face split with compensation, this increase in UA-value stays around $7 \%$ as $F_{\text {air }}$ decreases, however, the interlaced with compensation shows a decrease from $4.9 \%$ to $1.5 \%$ increase. The COP increases from $1.6 \%$ to $2.4 \%$ increase for the face split evaporator with compensation as $F_{\text {air }}$ decreases, however, the interlaced evaporator with compensation shows a decrease from $1.0 \%$ to $0.3 \%$ increase.

\section{Discussion}

The benefits shown in section 3.3 are at compensation for similar airflow maldistribution in each coil. However, there could also be coil to coil airflow maldistri- 
Interlaced
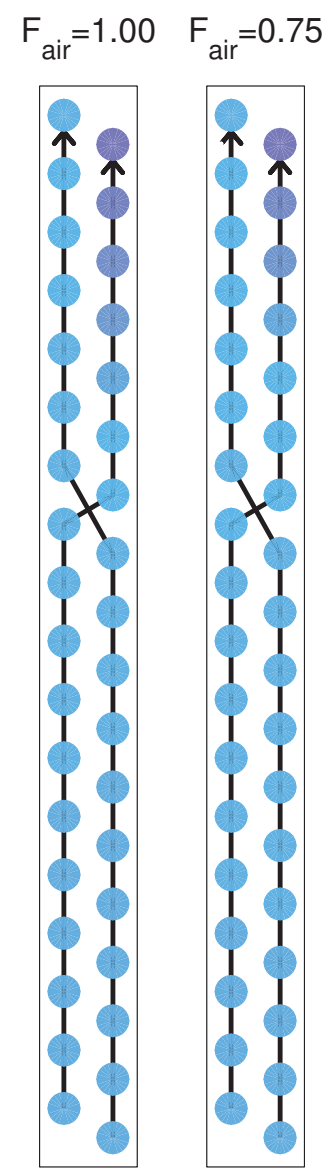

$\mathrm{F}_{\text {air }}=0.75 \quad \mathrm{~F}_{\text {air }}=0.50 \quad \mathrm{~F}_{\text {air }}=0.25$

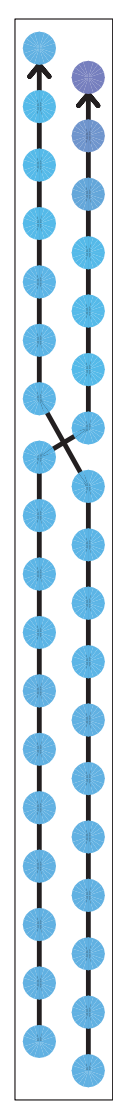

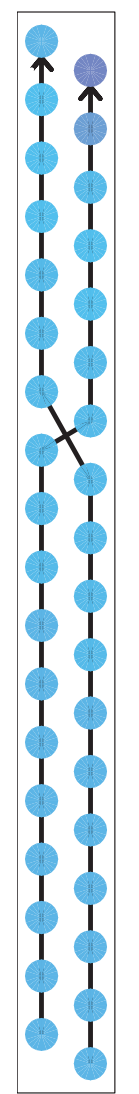

Face split
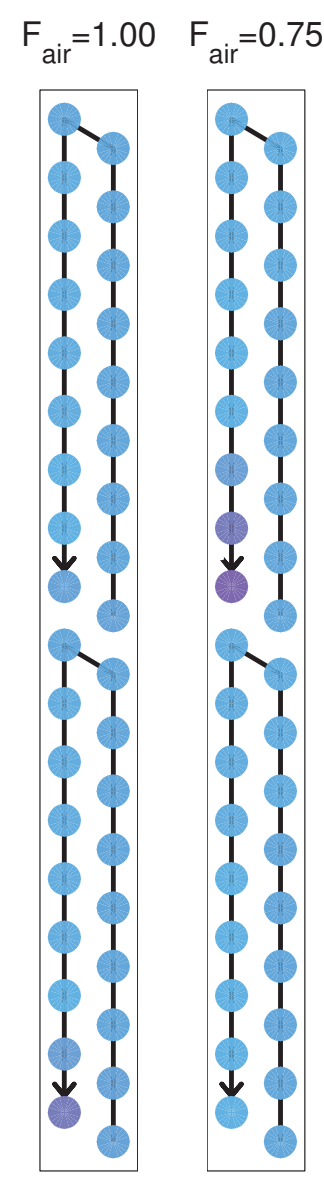

[K]

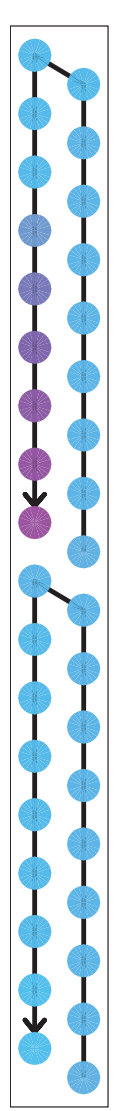

$\mathrm{F}_{\text {air }}=0.25$

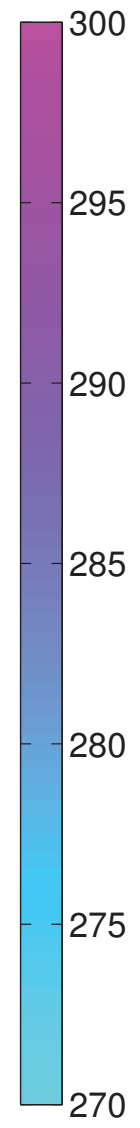

Figure 9: Refrigerant temperature contours through center of coils.

$\mathbf{a}$

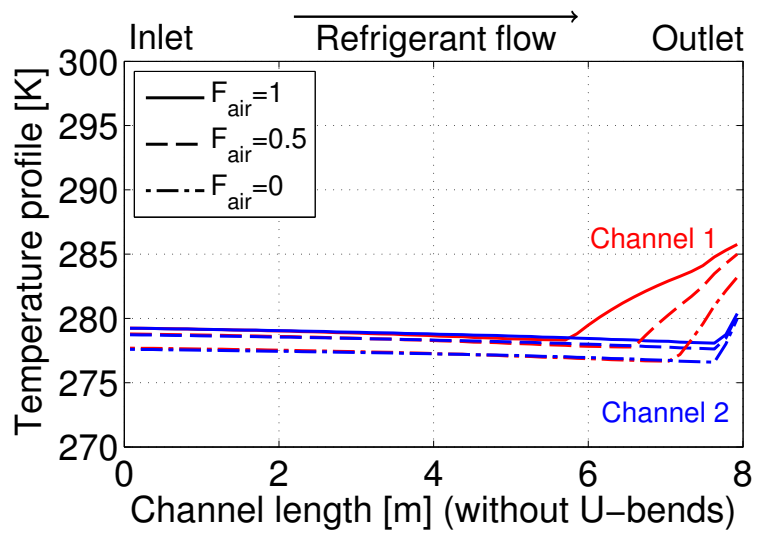

b

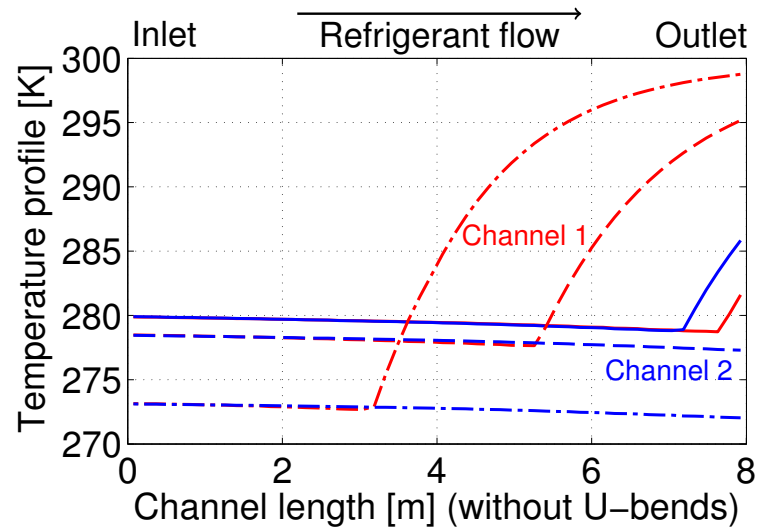

Figure 10: Refrigerant temperature profile for interlaced (a) and face split (b) coils at different airflow distribution parameters. 
$\mathbf{a}$

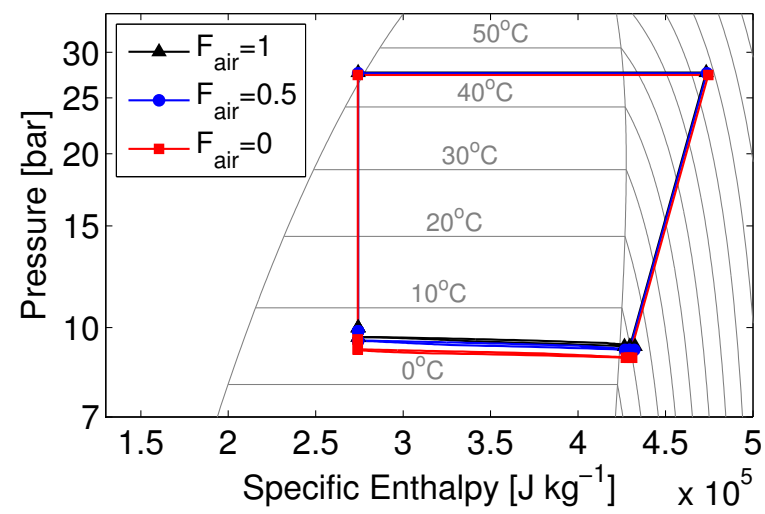

c

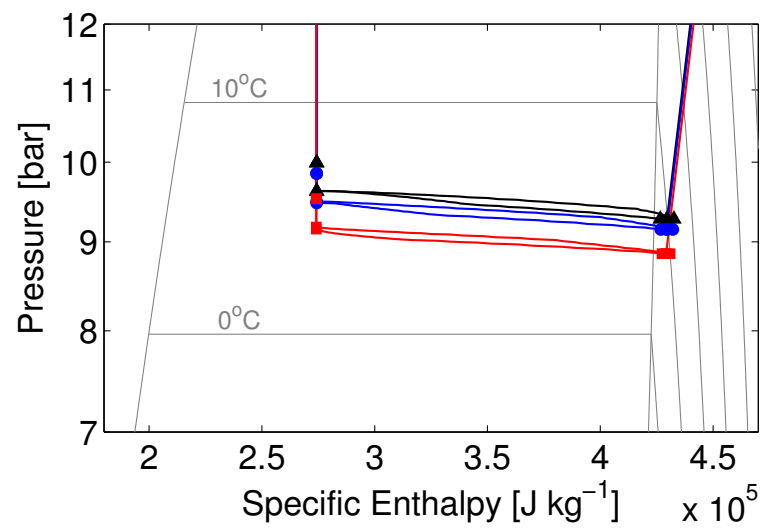

b

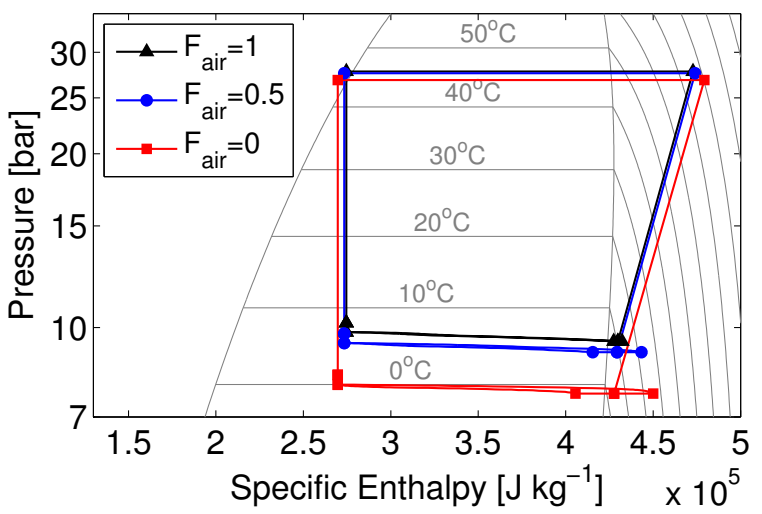

d

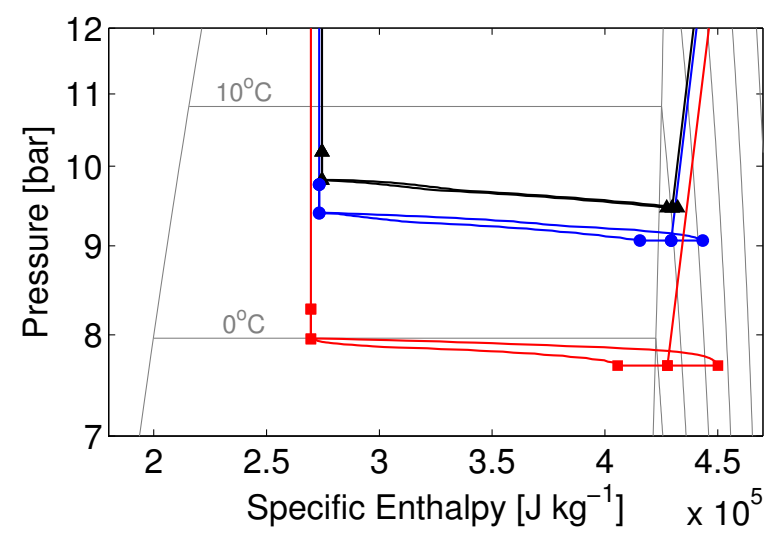

Figure 11: $\log p-h$ diagram for interlaced $(\mathrm{a}, \mathrm{c})$ and face split $(\mathrm{b}, \mathrm{d})$ systems at different airflow distribution parameters.

bution. There could also be non-uniform liquid/vapor distribution in the distributor as addressed in section 3.1 or other kinds of maldistribution, e.g. fouling. These issues may contribute to the total degradation of flow maldistribution. Maldistribution may also be worse when the system is in part-load operation or operated under off-design conditions. Thus higher benefits are expected in practice than showed in section 3.3, when applying the control of individual channel superheat.

The results of this paper may be used to predict the possible degradation or compensation in overall UAvalue and COP at flow maldistribution in the evaporator for the current system and evaporator circuitries. It is however difficult to estimate the phase and airflow distribution parameters $\left(F_{x}\right.$ and $\left.F_{\text {air }}\right)$. Practically, the transverse velocity profile is non-linear and the airflow through the face of the coil is a two-dimensional flow (not only changing in transverse direction but mainly). Essentially, the transverse velocity profile for a given A-coil depends on many factors such as apex angle, mounting brackets, condensate pans, upstream and downstream flow obstructions, bends or blower locations in the duct system. For example in studies using computational fluid dynamics (CFD) by Yashar et al. (2008), AbdelAziz et al. (2008) and Kærn and Tiedemann (2012), the transverse velocity field showed a recirculation zone with low air velocities inside the coils located farthest away from the apex. In a later study by Yashar and Domanski (2010) on another A-coil, no recirculation zone was found, thus several flow distributions may be present in a practical A-coil. Furthermore, these investigations were made at uniform and undisturbed upstream airflow, which may not be the case at installation of these systems.

The reader may use our results by making a qualitative estimate on the degree of flow maldistribution $\left(F_{x}\right.$ and $\left.F_{\text {air }}\right)$ considering the actual distributor and airflow arrangement. 
$\mathbf{a}$
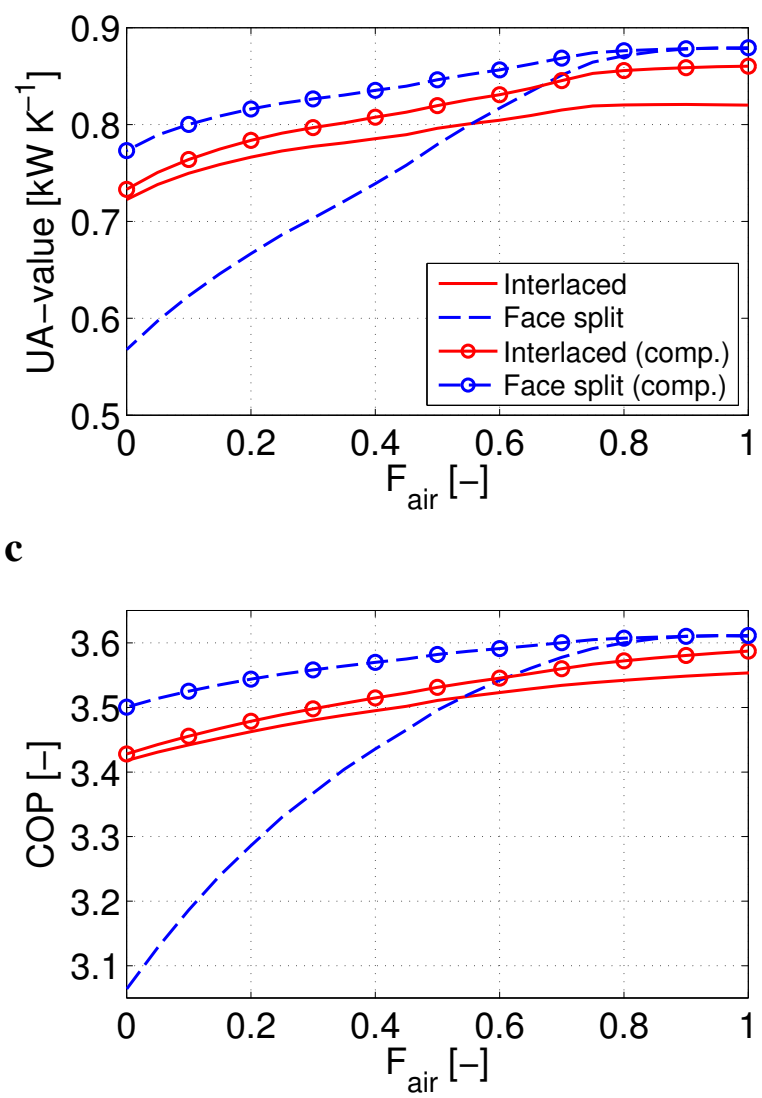

b

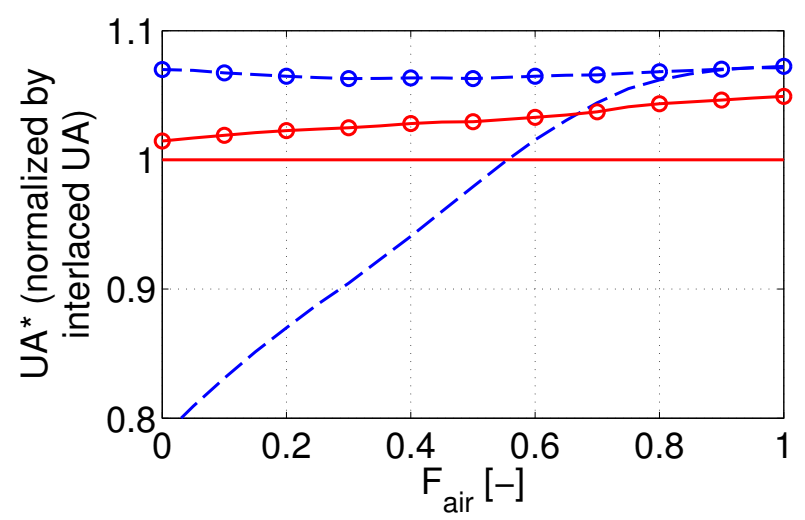

d

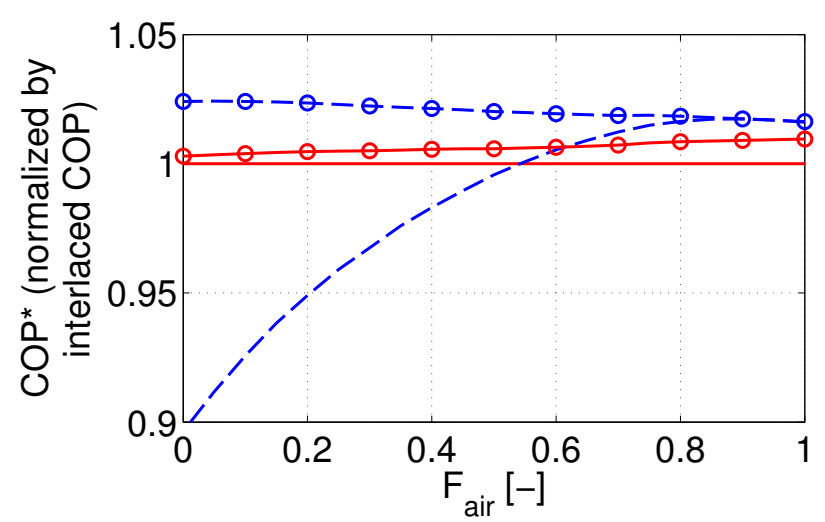

Figure 12: Comparison of UA-value and COP with and without compensation of airflow maldistribution.

In addition, it is difficult to extrapolate the results directly to larger evaporator coils with more refrigerant channels or other circuitries and operating conditions. Note that the phase distribution parameter $F_{x}$ is only defined for coils having two refrigerant channels, however the definition of the airflow distribution parameter $F_{\text {air }}$ is general. Furthermore, we did not consider dehumidifying conditions in this study and how dehumidification may influence the performance degradation due to maldistribution. Recently, Kærn and Tiedemann (2012) studied airflow maldistribution and compensation potentials in larger size evaporators $(17.6 \mathrm{~kW})$ with similar circuitries in both wet and dry conditions. The readers are referred to this reference for more detailed results with regards to larger size evaporators and wet conditions.

\section{Conclusion}

We conclude that at uniform flow conditions, it is always better to place the superheated regions with low UA-value in the first tube row of the coils, where the temperature driving potential is highest as done in the face split evaporator. The interlaced evaporator is only better than the face split evaporator at $F_{x}<0.55$ or $F_{\text {air }}$ $<0.55$, because it compensates flow maldistribution by design. Thus, we may conclude that significant flow maldistribution conditions occur in these evaporators, because of the interlaced evaporator usage.

If the flow maldistribution is controllable in a way that is independent of circuitry, as done in section 3.3, then the face split circuitry will give the best performance. Compared to the interlaced evaporator without compensation, the increase by using the face split evaporator with compensation is $7 \%$ in UA-value and $1.6 \%$ to $2.4 \%$ in $\mathrm{COP}$.

AbdelAziz, O., Singh, V., Aute, V., Radermacher, R., 2008. A-type 
heat exchanger simulation using 2-d cfd for airside heat transfer and pressure drop. In: 12th International Refrigeration and AirConditioning Conference at Purdue. No. 2200. West Lafayette, IN, USA

ANSI/AHRI Standard 540, 2004. Standard For Performance Rating Of Positive Displacement Refrigerant Compressors And Compressor Units. Air-Conditioning, Heating, and Refrigeration Institute, Arlington, VA 22201, USA

Blasius, P. R. H., 2002. VDI WÄrmeatlas, 9th Edition. SpringerVerlag Berlin Heidelberg New York.

Domanski, P. A., Yashar, D., 2007. Application of an evolution program for refrigerant circuitry optimization. In: ACRECONF "Challenges To Sustainability". New Delhi, India.

Dymola 7.4, 2010. Dynamic Modeling Laboratory, version 7.4. Dynasim AB, Research Park Ideon SE-223 70, Lund, Sweden.

Funder-Kristensen, T., Nicolaisen, H., Holst, J., Rasmussen, M. H. Nissen, J. H., 2009. Refrigeration system. US Patent, Pub. No.: US 2009/0217687 A1.

Geary, D. F., 1975. Return bend pressure drop in refrigeration systems. ASHRAE Transactions 81, 250 - 264.

Gnielinski, V., 1976. New equation for heat and mass transfer in turbulent pipe and channel flow. International Chemical Engineering $16,359-368$

Ito, H., 1960. Pressure losses in smooth pipe bends. Transactions ASME, Journal of Basic Engineering 82, 131 - 143.

Kim, J.-H., Braun, J. E., Groll, E. A., 2009a. Evaluation of a hybrid method for refrigerant flow balancing in multi-circuit evaporators. International Journal of Refrigeration 32, 1283 - 1292.

Kim, J.-H., Braun, J. E., Groll, E. A., 2009b. A hybrid method for refrigerant flow balancing in multi-circuit evaporators: Upstream versus downstream flow control. International Journal of Refrigeration 32, $1271-1282$

Kærn, M., Tiedemann, T., 2012. Compensation of airflow maldistribution in fin-and-tube evaporators. In: 14th International Refrigeration and Air Conditioning Conference at Purdue. No. 2178. West Lafayette, IN, USA.

Kærn, M. R., 2011. Analysis of flow maldistribution in fin-and-tube evaporators for residential air-conditioning systems. Ph.D. thesis, Technical University of Denmark, Department of Mechanical Engineering, Kgs. Lyngby, Denmark.

Kærn, M. R., Brix, W., Elmegaard, B., Larsen, L. F. S., 2011a. Compensation of flow maldistribution in fin-and-tube evaporators for residential air-conditioning. International Journal of Refrigeration 34 (5), 1230 - 1237.

Kærn, M. R., Brix, W., Elmegaard, B., Larsen, L. F. S., 2011b. Performance of residential air-conditioning systems with flow maldistribution in fin-and-tube evaporators. International Journal of Refrigeration 34 (3), $696-706$.

Mader, G., Thybo, C., 2010. An electronic expansion valve with automatic refrigerant distribution control. In: Deutsche Kälte-KlimaTagung. Magdeburg, Germany.

Müller-Steinhagen, H., Heck, K., 1986. A simple friction pressure drop correlation for two-phase flow in pipes. Chemical engineering and processing 20, $297-308$.

Payne, W. V., Domanski, P. A., 2003. Potential benefits of smart refrigerant distributors. Final report No. ARTI-21CR/610-20050-01, Air-Conditioning and Refrigeration Technology Institute, Arlington, VA, USA

Schmidt, T. E., 1949. Heat transfer calculations for extended surfaces. Refrigerating Engineering, 351 - 357.

Shah, M. M., 1979. A general correlation for heat transfer during film condensation inside pipes. International Journal of Heat and Mass Transfer 22, $547-556$.

Shah, M. M., 1982. Chart correlation for saturated boiling heat transfer: Equations and further study. ASHRAE Transactions 88, $185-$
196.

Skovrup, M. J., 2009. Thermodynamic and thermophysical properties of refrigerants. Department of Energy Engineering, Technical University of Denmark, Nils Koppels Allé, Building 402, DK-2800 Lyngby, Denmark.

Wang, C.-C., Lee, C.-J., Chang, C.-T., Lin, S.-P., 1999. Heat transfer and friction correlation for compact louvered fin-and-tube heat exchangers. International Journal of Heat and Mass Transfer 42, 1945 - 1956.

Yashar, D. A., Cho, H. H., Domanski, P. A., 2008. Measurement of air-velocity profiles for finned tube heat exchangers using particle image velocimetry. In: 12th International Refrigeration and AirConditioning Conference at Purdue. No. 2195. West Lafayette, IN, USA.

Yashar, D. A., Domanski, P. A., 2010. Air flow distribution through an a-shaped evaporator under dry and wet coil conditions. In: 13th International Refrigeration and Air-Conditioning Conference at Purdue. No. 2100. West Lafayette, IN, USA.

Zhang, W.-J., Zhang, C.-L., 2006. A generalized moving-boundary model for transient simulation of dry-expansion evaporators under larger disturbances. International Journal of Refrigeration 29, 1119 $-1127$ 